\title{
Rethinking survival, renewal, and growth strategies of SMEs in Bangladesh: the role of spiritual leadership in crisis situation
}

\author{
Ariful Islam
}

Putra Business School (AACSB-Accredited), University of Putra Malaysia (UPM), Serdang, Malaysia

Nur Fadiah Mohd Zawawi

Faculty of Entrepreneurship and Business, University of Malaysia Kelantan, Kelantan, Malaysia, and

\author{
Sazali Abd Wahab \\ Putra Business School (AACSB-Accredited), University of Putra Malaysia (UPM), \\ Serdang, Malaysia
}

\begin{abstract}
Purpose - For Bangladeshi small and medium enterprises (SMEs), the COVID-19 economic shock is remarkable in both its complexity and intensity. SMEs need systemic inspiration to solve the crisis, aligned with a moral and authentic approach that serves both the leader and the follower's interests. This study aims to conceptualize the innovation-focused success method of SMEs before and after the pandemic to manage the crisis by establishing spiritual leadership based on Islamic perspectives.

Design/methodology/approach - To discuss the impact of spiritual leadership on innovation-focused SME performance configuration through the lens of a crisis, a comprehensive literature study has been carried out in which over 360 articles are read and reviewed by the authors. It has also established the reliability and validity of literature analysis. Also, a qualitative investigation has been used to support the direction of the study.

Findings - For a subsequent process of scientific deployment and evaluation of its execution, a new applied strategic innovation-focused SME success configuration through spiritual leadership development is made available. The primary value of this paradigm is the potential to calculate and treat the aspects of spiritual leadership obtained from Islamic ideas.

Research limitations/implications - Prior analytical or empirical attempts from multiple viewpoints are subsequently needed to inquire about the proposed conceptualization.

(C) Ariful Islam, Nur Fadiah Mohd Zawawi and Sazali Abd Wahab. Published in PSU Research Review. Published by Emerald Publishing Limited. This article is published under the Creative Commons Attribution (CC BY 4.0) licence. Anyone may reproduce, distribute, translate and create derivative works of this article (for both commercial and non-commercial purposes), subject to full attribution to the original publication and authors. The full terms of this licence maybe seen at http:// creativecommons.org/licences/by/4.0/legalcode

This paper and the research behind it would not have been possible without the exceptional influence of Late Allama Ahmad Shafi. He was a renowned Islamic scholar of the subcontinent who penned a number of books - 13 in Bangla and 9 in Urdu. His enthusiasm, knowledge, emphatic views, and wisdom have always been an inspiration for Ariful Islam and kept his work on track.
\end{abstract}

Received 6February 2021 Revised 27 April 2021 Accepted 30 April 2021 
Practical implications - Among the realistic consequences of this analysis is that while a number of leadership paradigms have been embraced by a broad body of leadership studies, the findings indicate that this paper should pay heed to the influential spiritual style of leadership, taking into account Islamic perspectives on the context of crisis. Therefore, Bangladeshi SMEs need to develop and run leadership training programs focused on the Islamic viewpoint of spirituality to encourage the actions of leaders during and after crises.

Social implications - The legal and moral values of the society would ultimately be upgraded from this conceptualization. Moreover, less corruption in corporate activities would improve the economic prosperity of a nation. It would also contribute to the cross-cultural portrayal of the positive picture of Islam.

Originality/value - This holistic conceptualization describes the mediating role of strategic innovation practices based on theoretical foundations, which have seldom been done in previous research, between the Islamic model of spiritual leadership and SME success during and after a crisis.

Keywords Innovation, SMEs, Spirituality, COVID-19, Al-Quran, Tawheed

Paper type Conceptual paper

\section{Introduction}

The present globalization scenario has created a platform for small and medium enterprises (SMEs) to play a critical role in the country's economic success. This sector is a dominant component of every economy and is seen as an active turbine of the economic system of the entire globe. They account for about $90 \%$ of business entities and more than $50 \%$ of global jobs (World Bank, 2020). In particular, considering emerging economies, formal SMEs contribute up to $40 \%$ of national income (gross domestic product [GDP]). In this direction, SMEs contribute $25 \%$ of overall GDP to $40 \%$ of manufacturing production in the case of Bangladesh but can contribute more (ADB, 2013). SMEs are the bloodline of the economy in Bangladesh, generating more than 7.8 million jobs. Indeed, their significance is such that SMEs have arisen as a potentially separate group for research purposes (Saunders et al., 2014). However, the destructive and ruthless effects of the COVID-19 pandemic have already been witnessed by SMEs of Bangladesh (Islam et al., 2020A). Around 28\% of Bangladeshi SMEs have registered significant declines in their sales, while $52 \%$ of SMEs have been forced to quit their business because of the lack of raw material supply and the lack of scope to market their goods (LightCastle, 2020). In addition, $46 \%$ of Bangladeshi SMEs expect to fire more than $50 \%$ of their workers within four months if the condition does not change. In this critical intersection, to endure the crisis period and achieve business results, a firm needs an appropriate form of leadership (Bowers et al., 2017; Hong et al., 2012).

Most of the business organizations facing a crisis hold a tendency to rely on the leader in charge to lead them out of the crisis (Stern, 2017). Unfortunately, though, recurring dishonest controversies, financial misconduct, immoral management methods have demonstrated that all dominant or conventional leadership programs have struggled to deliver adequate crisis leadership that can perform beyond their personal benefit or gain (Brown and Mitchell, 2010; Conger, 1990; Haynes et al., 2015). Here, we have also noted that spirituality has been known to have a strong connection with the phase of business stability or resilient process through crises or uncertainties (Bouckaert and Zsolnai, 2011; Kovács, 2020). At this point, the "spiritual" element of leadership dilemma may serve a moral and authentic holistic motivation and embody the needs of both the leader and the follower. Spirituality is one of the fundamental needs that leadership needs to fulfill, according to Fry (2003). Furthermore, Reave (2005) notes a "clear consistency" in what she describes as holistic principles such as dignity, authenticity and modesty and spiritual behaviors related to leadership effectiveness after evaluating over 150 reports. In fact, several scholars contend that spiritual leadership on basis of religion should be specifically connected to faith 
(Benefiel and Abbott, 2019; Fernando and Jackson, 2006). In view of this direction, we argue that the incorporation of Islamic principles in the outline of spiritual leadership can clearly include deliberate reflection and contemplation of Allah SWT, faith as the basis for the encouragement for the organization to do just deeds. It may construct an adaptable corporate culture (Burrell, 2021) focused on the ideals of altruistic love within SMEs, whereby leaders and followers have a sense of membership and belonging and feel valued and respected (Figure 1). In a crisis, material and spiritual pursuits are inseparable for Islamic business leaders, and any move is a religious act.

In response to this call, we expect that spiritual leadership integrates spiritual qualities that are fundamental to Islamic principles, and hence, has the potential to provide the basis for a comprehensive SME performance model to confront the present crisis in Islamic tenets through spiritual leadership development. Interestingly, however, a variety of scholars have attempted to configure a non-secular type of SME success paradigm guided by leadership to confront various crises focused on Western theological viewpoints (Illes, 2014; Firestone, 2020; Mabey et al., 2017; White, 1986), although very few accepted Islamic ideas or principles (Akhtar et al., 2017; Egel and Fry, 2017). In comparison, very few literatures cover our target field considering Muslim emerging regions such as Bangladesh to illustrate the required resilient path for the SMEs concerned. The segment of secular scholars may have restricted access to Islamic literature, but that is also because of the fact that the complexity and immense scale of Bangladesh's Muslim community has resulted in many different applications of Islamic beliefs and ethics (Nisha and Iqbal, 2017). The purpose of this conceptual paper is, therefore, to control the performance of Bangladeshi SMEs in terms of survival, renewal and growth phases to navigate the crisis time through the development of spiritual leadership based on Islamic principles to establish a consensus of the above claims. We also believe that scholars have seriously underestimated the intervention of exploratory and exploitative innovation practices between spiritual leadership and SME performance in view of the crisis scenario. The negotiation of innovation initiatives can support the whole conceptualization from a strategic viewpoint that is currently supported by the studies of Saunders et al. (2014) and Naidoo (2010), contributing to more resilient results. Finally, the objective would answer our research question on how spiritual leadership will help boost the performance of Bangladeshi SMEs in terms of innovation during survival, renewal and growth phases to resolve uncertainties.

The spread of epidemics in human populations and business operations is still a significant crisis (Islam et al., 2021). Bieber (1988) demonstrated that the crisis could lead

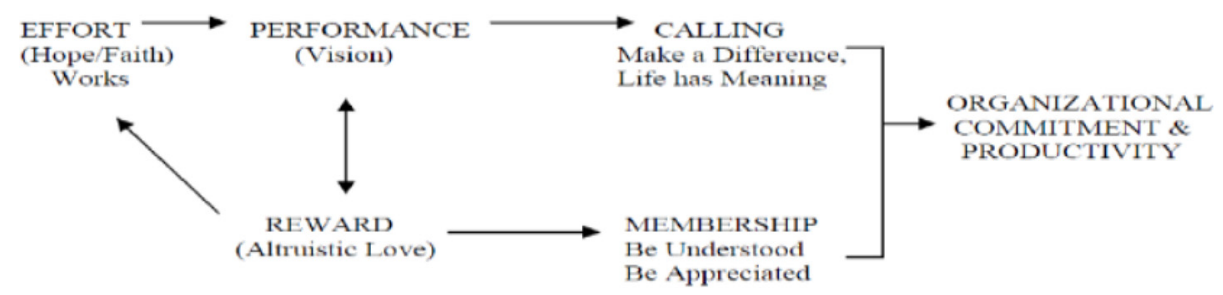

Leader values

Attitudes, \& behaviors

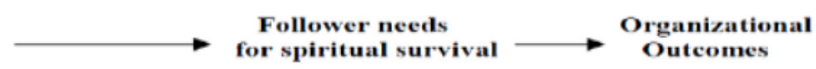

Source: Fry (2003)
Role of

spiritual

leadership in crisis situation

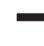


to undesired consequences as a turning point from chaotic circumstances. Here, we argued that Islam was the first to begin setting down empirical and realistic crisis management techniques, and this was obvious through the Al-Quran and Hadith directives (Ramli et al., 2014). The wise and innovative leadership of the Prophet Muhammad was the pillar of success in discovering crisis-solving techniques considering different scenarios that management scientists did not realize until today (Al Eid and Arnout, 2020).

In fact, this research seeking acceptable spiritual leadership configuration for Bangladeshi SMEs; suffering from a crisis is focused on the teaching of Islamic primary sources, the Al-Quran and Hadith, in the face of these edges. The direction contends that in today's competitive world, this newly coined holistic idea provides firms with a more reliable, systematic and long-term configuration for business success. The major inspiration for this study is to add to the ongoing pool of Islamic entrepreneurship studies that could play a role in developing effective business models linked to cross-cultural settings. The following part will analyze the methodology of this study before delving into the ideas of supplementary background, SME performance in crisis, strategic innovation, spiritual leadership and explorative outcomes. After that, the research question would be answered, before the impact of spiritual leadership is introduced as a new direction for SME's holistic crisis handling model.

\section{Methodology}

Initially, a systematic literature review of the study is based on a method of selecting and evaluating research contributions that are formal, straightforward and reproducible. We also followed the steps recommended by Hart (2001) for performing a literature review analysis:

- locating information references;

- locating related articles; and

- locating item reviews.

The authors began with the selection of several databases such as Web of Science, Scopus, Journal Storage, Science Direct, Springer, Scientific Advisory Group for Emergencies, Multidisciplinary Digital Publishing Institute and Emerald. We were able to compile a complete list of related research papers because of the combination of database types. Finally, 360 publications were rated depending on their content. We have searched for similarities between the research papers when reviewing them. During the analysis, reliability was targeted by examining the procedural steps of Hart (2001). The literature analysis was carried out by three reviewers and both of the interventions were discussed before and after to increase inter-rater reliability during the literature analysis (Seuring and Müller, 2008). Validity was followed on the basis of current standards through sampling papers (Hart, 2001), and constructs from prior written literature reviews were compared within and beyond the field of research (Fagerberg et al., 2012). In addition, at conferences and seminars, ongoing scholarly work on this analysis was also addressed, allowing other researchers to comment on the work-in-progress process.

Afterward, a qualitative investigation design was used in conjunction with the purposive judgmental sampling process for our study. As participants of the interview process, SME decision-makers (e.g. Director, Manager, Asst Manager, etc.) from the Chittagong region were chosen. However, the study's original goal was for 9-10 interview sessions, but data saturation related to our target was achieved so quickly that no new codes were generated 
from the last few interviews. The semi-structured interview protocol was used in this case because of its suitability for eliciting observations to help the study's expected conceptualization. All the interview sessions were conducted via WhatsApp video chat option and lasted approximately $8-10 \mathrm{~min}$ based on scheduled appointments. The entire process was finished within several weeks timeline. Both online meetings with reflected members were audiotaped and transcribed verbatim, and the transcripts were loaded into coding and analysis tools. The protocols pertaining to interviews, audio recording and coding tasks were all carried out by a single researcher, ensuring the optimum level of familiarity with the collected data. Furthermore, non-governmental agency publications, theses, project documents and documentary videos were used as sources of supporting material for the research. At this stage, the triangulation of the analyzed data has been developed to improve the validity and reliability of the research method.

\section{Supplementary background of the study}

Bangladesh v/s west: a paradox of educational systems

Academic curriculums in western countries would almost certainly result in generations striving for Western Secular goals, which may be a source of contention from an Islamic standpoint. However, for divine or holistic ability, the Western Secular outline has the potential to improve all human potentials (Ali, 2016). However, it has been noted that many Muslim scholars are fascinated by some aspects of the Western perception of a business, especially when it comes to the domain of entrepreneurship. Here, it is important to note that Bangladesh's specific academic framework contains overt and implied issues relating to the community's ethics, especially religious and moral values. In comparison to the Western system, Bangladesh's public education outline provides a mix of materialistic and religious education at the primary and secondary stages (Roy et al., 2020). Religion is taught separately as a compulsory subject to students from the four main faiths (Islam, Hinduism, Buddhism and Christianity) beginning in Grades 3rd to 10th. Surprisingly, in Bangladesh, the Madrasa education outline coexists with the conventional education system (Rahman, 2020). Alia madrasas sponsored by the government often follow a hybrid model that teaches both conventional and religious subjects concurrently from primary to secondary levels. Recently, the Quomi Madrasas were active in recent talks with the government, resulting in acknowledgment of their highest degree, Dawrah-i-Hadith, which is equal to a master's certification (The Daily Star, 2018). Another vital point of note is that a lot of Bangladeshi students attend both Madrasa and Secular institutions (Nelson, 2008). In truth, Madrasas are being challenged as part of national education to produce quality graduates with economic insight and an entrepreneurial spirit (Sultana and Kabir, 2018). This economic spirit may also be derived from the Prophet Muhammad's example of entrepreneurship to improve things (Mebroui and Mosbah, 2020). Furthermore, conventional and religious subjects are taught at many private and public universities in Bangladesh. In addition, the Bangladesh Institute of Islamic Thought and the Islamic Research Center Bangladesh at Bashundhara are two of the most prestigious Islamic strategic think tanks in the country. In reality, the ultimate scenario calls for a full-fledged business program based on Islamic values derived from Al-Quran and Hadith, as well as the introduction of an inclusive and viable entrepreneurship education configuration for all Bangladeshi students, by combining the current dual structure of comprehensive education curriculums.

\section{Corporate corruptions and small and medium enterprises}

Corruption is almost common around the globe, but the magnitude, form and repercussions vary greatly (Warf, 2017). According to the ACCA (2019) poll, almost 64\% of SMEs

\section{Role of spiritual} leadership in crisis situation

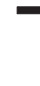


worldwide view bribery and corruption as a risk to business output. This is an alarming rise from 2013 when the statistic was just 43\%. Though recognition is increasing, the majority of SMEs $(59 \%)$ feel there is insufficient guidance to assist them in identifying and dealing with cases of multiple corporate wrongdoings. Interestingly, according to CFI (2015), firms operating under Islamic foundations can become more competitive due to their strict moral and ethical guidelines. Nonetheless, businesses driven by clear Islamic values are less likely to engage in trade manipulation or corporate corruption (Wilson, 2006). From another perspective, it is worth noting the pattern of combating corruption in the private sectors in Muslim and Muslim-majority countries. According to the Corruption Perceptions Index (CPI, 2020), no Muslim country is ranked in the top 20 (of the 180 countries surveyed) in terms of corruption. With 88/100 points, New Zealand and Denmark lead the world. Bangladesh is currently ranked 146 th, with a score of $26 / 100$. This is a colossal failure of a model Muslim society that upholds a high level of integrity. In fact, much of the core values of Western countries, such as openness, dignity, responsibility, democracy, human rights and justice, are fundamental values that do not contradict Islam or any other religion and are essential components of Islamic understanding (Satar, 2019). We believe that the most effective way to prevent corruption in the private sector of Muslim and Muslim-majority countries is to restore solid ethical and moral standards built on an Islamic foundation and to enforce an acceptable Islamic management framework. To maintain a respectable reputation during a crisis, businesses must adhere to working on a legal or spiritual basis to please new customers and existing stakeholders. When opposing to other ideas, the advancement of spiritual leadership based on Islamic values (Islam and Abd Wahab, 2021a) seems to be a systematic approach for a firm's business success at this time.

\section{Small and medium enterprises and community services}

Many Western theorists have sought to provide scientific, legal and ethical foundations for firms' community services efforts. These efforts have been widely criticized for issues with logic, conceptual clarification and potential contradictions, as well as for failure to offer sufficient ethical or moral advise to corporate decision-makers (Khurshid et al., 2014). Community programs associated with philanthropic domains may or may not be considered a CSR (corporate social responsibility) action in various Western areas of the world. As a result, the European Commission expressly omitted philanthropy from the CSR outline because it is closely connected with religion or charity (Maldonado-Erazo et al., 2020). It should be remembered that the Church of England's attendance has dropped by $27 \%$ since 1980 (Brammer and Millington, 2003). As per this note, philanthropic or charitable donations by USA corporations plummeted nearly $14.5 \%$ past year and corporate giving as a percentage of earnings has fallen by $50 \%$ over the past 15 years of the timeline (Porter and Kramer, 2002). Where it comes to Western countries, the deterioration in the importance of faith or religion is most noticeable among the youth segment (Brammer and Millington, 2003). In practice, stakeholder's preferences can be especially influential in formulating a firm's community engagement activities. On the opposite, the institutional form of Islamic charities (e.g. Zakat, Sadakah, Infak, etc.) may be a huge source of vast economic capital (e.g. approximately US $\$ 1 \mathrm{tn} /$ year) dedicated to the growth of society's vulnerable segments (Benthall, 2016). Unfortunately, Islamic institutional charities around the world operate in a dysfunctional configuration, raising concerns about their long-term viability and capitalization of potential development. At present, more than 3 billion population are living in poverty of which $35 \%$ are from Muslim regions (Hoque et al., 2015). However, Muslims can permanently eradicate poverty and dramatically grow their society by fostering an 
Islamic value-driven entrepreneurship mechanism to mobilize charitable funds in a responsible and deliberate manner.

Religious principles and beliefs can play an important role in inspiring business firms to respond to people's immediate needs and partially filling social needs left unfilled by the authorities in South Asia (Ali and Hatta, 2014). Some Sharīah-compliant companies in Bangladesh (e.g. Islami Bank Bangladesh Limited, Al Arafa Islami Bank Limited, etc.) are active in community programs related to health, education, food security, disaster relief and environmental problems based on beneficiary satisfaction (Hossain and Yahya, 2017). According to Mohiuddin's (2017) research, Bangladeshi firms led by Islamic values are better suited to provide a variety of community services and charities than their conventional counterparts. The main objectives of the Islamic business culture are not strictly materialistic, but rather are focused on the ideals of human well-being and the attainment of a decent life (Ramadani et al., 2015). In this context, community services do not merely refer to tactical or instrumental acts taken by firms to generate goodwill or long-term business success. This may serve to legitimize the continued existence of corporate entities in society. It is anticipated that Islamic values can induce a significant impact on stakeholders' views of community engagement. Indeed, businesses should use their community service activities focused on Islamic principles to enhance their competitive context - the consistency of the market environment in the place or locations where they work. This strategic environment aligned with holistic views has always been critical to a firm's business growth outline (Cha and Rew, 2018).

\section{Small and medium enterprise performance}

Firm performance toward success in management research is one of the most relevant constructs. According to Richard et al. (2009), the performance of SMEs includes three basic aspects of the company, namely, financial performance (profits, return on cash, return on investment, etc.); the performance of the commodity market (e.g. sales, market share, etc.); and the return for shareholders (total shareholder return, economic value-added, etc.). SMEs suffer from financial loss, decreased market volume, incapacity to satisfy contract terms, cash-flow challenge, decrease in employee numbers and even closing of the company at or after disaster incidents due to disruptive performance levels (Beraha and Đuričin, 2020). It is, therefore, necessary for researchers to find a configuration to change or adjust the degree of SME output during and after the crisis, resulting in market success or long-term survival (Islam et al., 2020A).

Again, leadership and HR are crucial to preserving the optimal SME success standard during crisis events. In view of the study's course, the survival phase of SMEs deals with a short-term goal that is representative of profitability given the crisis scenario (Bourletidis and Triantafyllopoulos, 2014; Cucculelli and Peruzzi, 2020; Park et al., 2019). Again, the renewal of SMEs is the mechanism of transition and the result of strategic path changes that have the ability to assess a firm's sustainable competitiveness (Agarwal and Helfat, 2009; Moretti et al., 2020). In addition, growth signals a company's long-term success or sustained development (Chittithaworn et al., 2011; Miroshnychenko et al., 2020). SMEs need to rapidly customize their tactics and reorganize their courses of action in the face of the present threat, given priority to the survival, renewal and growth stages of crisis management (Herbane, 2019). In this juncture, the following metrics (Table 1) for SME performance before and after the crisis are often served by the systematic analysis and pre-existing scales to assess the anticipated validity and reliability of future research. 


\section{PRR}

Table 1.

Proposed measurements for survival, renewal and growth phases

\begin{tabular}{|c|c|c|}
\hline Phase & Items & Source \\
\hline Survival & $\begin{array}{l}\text { Our firm has an active business survival } \\
\text { plan during crisis } \\
\text { Our firm has the provision for employees to } \\
\text { work from home } \\
\text { The employees of our firm know what to do } \\
\text { in a pandemic } \\
\text { I am confident that our employees will stay } \\
\text { to help protect key business assets } \\
\text { The firm has been doing emergency } \\
\text { communication with suppliers and } \\
\text { customers } \\
\text { Our firm has a clear strategy regarding } \\
\text { cash-flow management }\end{array}$ & $\begin{array}{l}\text { Bourletidis and Triantafyllopoulos (2014); } \\
\text { Islam et al. (2020A); Park et al. (2019) }\end{array}$ \\
\hline Renewal & $\begin{array}{l}\text { Our firm has adjusted its corporate strategy } \\
\text { into a new direction } \\
\text { Our firm has been analyzing each of the } \\
\text { products or services, one by one, for } \\
\text { strategic importance, significance and } \\
\text { profitability } \\
\text { I believe that learned lessons during a } \\
\text { pandemic will help the firm to reset a new } \\
\text { foundation and way forward to success } \\
\text { There has been the implementation of new } \\
\text { management practices }\end{array}$ & Agarwal and Helfat (2009) \\
\hline Growth & $\begin{array}{l}\text { There is an improvement in terms of sales, } \\
\text { revenue generation and market share } \\
\text { There is a rise in profitability } \\
\text { There is an increase in the number of } \\
\text { customers } \\
\text { There is an improvement in our product or } \\
\text { service image } \\
\text { We comply with relevant pandemic/ } \\
\text { emergency regulations }\end{array}$ & $\begin{array}{l}\text { Chittithaworn et al. (2011), Miroshnychenko } \\
\text { et al. (2020) }\end{array}$ \\
\hline
\end{tabular}

Source: Developed by authors

\section{Scaling innovation as a strategic intervention}

Although crises may have catastrophic impacts on economies and communities, they also offer an impetus for the competitive survival and growth-driving renewal phase of the business. In this way, in reaction to the crisis, we refer to innovation activities as the strongest realization of strategic initiative (Islam and Abd Wahab, 2021b; Juergensen et al., 2020). Reymen et al. (2015) indicate how businesses, in the face of environmental risks, are starting to seek innovative options, extend their operations to other markets and focus on new ways of doing business. In addition, in reaction to the crisis, some scholars have emphasized the importance of complementary assets for adapting and broadening the reach of business activities. Several reports at this level indicate that strategic innovation initiatives can be important strategic solutions for businesses confronting the crisis (Paunov, 2012). Several recent studies also argue that while businesses tend to minimize innovation tactics in the light of economic crises in general, implementing innovative and constructive initiatives will allow companies to solve the crisis and increase their innovative performance and turnover recovery (Archibugi et al., 2013; Shirokova et al., 2020). Other 
studies also uncovered the role of leadership in the mechanism of innovation practices in the crisis management domain (Looser, 2020; Rainey, 2010).

\section{Explorative and exploitative forms of innovation}

The study of March (1991) narrowly describes exploration as "search, variation, risk-taking, experimentation, play, flexibility, discovery and innovation," comparing it with exploitation that includes "refinement, selection, production, efficiency, selection, execution and execution" (p. 71). In fact, exploitative innovation creates value by strengthening the current knowledge base and upgrading existing goods or processes for businesses, while exploratory innovation creates value by developing new domains for companies or traveling to various domains to implement or produce new products or services (Zuraik and Kelly, 2019). The dilemma between exploration and exploitation has been found to provide distinct strategic pathways in secure conditions to boost company performance. For example, Auh and Menguc (2005) report that exploration leads to long-term success, based on a survey of 206 manufacturing companies, while exploitation is correlated with short-term performance. However, the implementation of these principles to innovation programs has, in practice, remained vague (Greve, 2007). Here, based on studies by Islam and Abd Wahab (2021a, 2021b), Sui and Baum (2014), we firmly argue that, in view of the current crisis, the equilibrium or combination of explorative and exploitative innovation approaches may have a huge effect on the survival, renewal and growth phases of SMEs (Table 2).

\section{Inclusion of spiritual leadership in the configuration}

In coping with the past business situation, it is not equivalent to what turbulence is going on today, and it also goes to the leadership style. The idea of spiritual leadership at this stage is an observable phenomenon that arises when an individual embodies spiritual ideals such as dignity, fairness and modesty by personal branding as a trustworthy, credible and praised role model when guiding a specific institution through a period of uncertain time. It is the probable solution to the turbulence that situational complexities such as belief systems and inner personal value systems generate during uncertainties (Kaya, 2015). Thus, with faith and piety, the spiritual form of leadership has a clear connotation. Proactive leaders are spiritual leaders who can modify the way others "see" and "act." They take on circumstances and affect the mindset and actions of other individuals to reach a shared purpose that will potentially favor the community or organization as a whole (Frisdiantara and Sahertian, 2012; Zhang and Yang, 2020). If accompanied by a conducive work ethic, this type of leadership will enhance the efficiency of organizations (Sholikhah et al., 2019). The introduction of the Islamic reinforcement into this model of leadership often encourages legitimacy over conventional authority, but rather over logical and legal structures founded on the unity of intent, acceptance of the one Allah, and the fundamental example of Prophet Muhammad (Adawiyah and Pramuka, 2017; Almoharby and Neal, 2013). However, from the Islamic point of view, the degree of carefulness of leaders impacts their success in the

\begin{tabular}{ll}
\hline Phase & Suitable strategy \\
\hline Survival & Exploitation \\
Renewal & Exploitation + exploration \\
Growth & Exploration
\end{tabular}

Source: Compiled by authors
Role of spiritual leadership in crisis situation

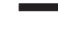


decision-making process regarding crisis scenarios (Anwar et al., 2020). At this juncture, one level of spirituality is faith and three dimensions of responsibility are identified to predict the success of business leadership, namely, righteousness, integrity and emotional balance (Rafiki, 2020).

The studies of bin Khalid (2019), Husti and Mahyarni (2019) claim that adopting the Islamic viewpoints within the style of spiritual leadership may have a positive and important influence on the success of organizations considering the involvement of sufficient innovative activities. It has the potential to foster the principles of Bid'a (innovation) and Ijtihad (critical legal thought in pursuit of solutions to new problems) within the organizations' critical decision-making process (Hasan, 2003). Furthermore, the attributes of spiritual business leaders with Islamic ideas may intend to promote resilient businesses and guide the adherents to become united and innovative (De Clercq et al., 2018; Rafiki, 2020). Given the Islamic historical perspective, this sort of spirit has been seen to be the great force to create noble leaders with high dignity or to confront different crisis times in Arabic "akhlakul karima" (Tobroni, 2015). In this notion, Al Eid and Arnout (2020) suggest that spiritual leaders with Islamic concepts must have the capacity to transcend beyond materialism, enhance everyday working life experiences, helping all adherents to appreciate their relationships. There is no question that these features are core aspects of crisis management (Abdelzaher et al., 2017). Based on the above discussions, we predict that the consistency of Islamic foundation-based spiritual leadership has the capacity to serve as a significant strategic resource that provides complex importance for the unpredictable survival, renewal and growth cycles of SMEs. We have to admit that the spiritual style of leadership does not equal anti-intellectual leadership. It is not only rational but also, in its conscience, purifying rationality itself.

\section{Dimensions of spiritual leadership}

In Islam, the leadership of the Prophet Muhammad (SAW) and the four Caliphs dominate religious, moral and theological aspects. The spiritual style of leadership is usually based on Sharī'ah's main and secondary instruments (Al-Quran and Hadith). In the Islamic outline, Safi (1995) indicated that leaders ought to have strong leadership skills to represent and direct their followers to accomplish organizational goals, such as persistence (sabr), conviction (yaqin), intelligence ('ilm), contact (fathonah), business (iqdam) and leniency (lin). Marbun (2013) also believes that trustworthiness, fairness, integrity, honesty, gratitude and bravery are virtues of Islamic leadership that demonstrate positive attributes in achieving trust among followers, customers and stakeholders.

The Islamic management research studies, on the other hand, stress that the consistency of Al-Quran and Hadith-based leadership consists of four key attributes: truthfulness-al-sidq (Jamil, 2015), faith-amanah (Gazi, 2020), knowledge-fathonah (Daud et al., 2014; Machmud and Hidayat, 2020) and coordination-tabligh (Mir, 2010). In reality, leadership qualities are critical for achieving high organizational efficiency, such as the ability to understand competently, the ability to react adequately to questions, the ability to acquire love and warmth of members, the propensity to make decisions after consulting, the encouragement of critique, the complex, severe and eager perception. However, in the recent Al Eid and Arnout (2020) report, Islamic leadership qualities were classified into personal, emotional and social viewpoints, taking into account the complexities of the crisis. As their persistence leads to tremendous human and economic casualties, a crisis must be faced and wisely handled. In fact, crisis management, therefore, demands distinct and innovative leadership, which has personal, emotional and social characteristics to confront uncertainties effectively (Table 3). 


\begin{tabular}{|c|c|c|c|c|}
\hline Leadership dimension & Feature & Phase of influence & Source & ole of \\
\hline Truthfulness (Al-Sidq) & $\begin{array}{l}\text { Give declaration against } \\
\text { unsuitable strategy or decision. } \\
\text { Keep commitment with } \\
\text { subordinates }\end{array}$ & Renewal & Jamil (2015) & $\begin{array}{l}\text { leadership in } \\
\text { crisis situation }\end{array}$ \\
\hline Trust (Amanah) & $\begin{array}{l}\text { Having a trustworthy nature } \\
\text { through his intentions and skills } \\
\text { to confront with crisis }\end{array}$ & Survival & Gazi (2020) & \\
\hline Communication (Tabligh) & $\begin{array}{l}\text { This helps the leader to } \\
\text { responsibly negotiate the } \\
\text { objectives with various } \\
\text { stakeholders through the severe } \\
\text { consequences }\end{array}$ & $\begin{array}{l}\text { Survival, renewal } \\
\text { and growth }\end{array}$ & Mir (2010) & \\
\hline Knowledge (Fathonah) & $\begin{array}{l}\text { Obtained understanding from } \\
\text { crisis/intelligence can help in long } \\
\text { time survival and provide the } \\
\text { ability to deal with future crisis }\end{array}$ & Growth & $\begin{array}{l}\text { Daud et al. (2014), } \\
\text { Machmud and } \\
\text { Hidayat (2020) }\end{array}$ & \\
\hline Patience (Sabr) & $\begin{array}{l}\text { Promotes resilience capability, } \\
\text { analytical decision-making and } \\
\text { strength during turbulence }\end{array}$ & Survival & $\begin{array}{l}\text { Al Eid and Arnout } \\
(2020)\end{array}$ & $\begin{array}{r}\text { Table } 3 . \\
\text { Major dimensions for } \\
\text { spiritual leadership }\end{array}$ \\
\hline \multicolumn{2}{|c|}{ Source: Developed by authors } & & & to endure crisis \\
\hline
\end{tabular}

\section{Theoretical underpinning of the study}

The Ambidexterity paradigm is an interesting topic of strategic management research that has evolved meteorically over the past 17 years (Hughes, 2018). The rationale behind the ambidexterity of innovation relies on the belief that combining exploration and exploitation increases efficiency rather than relying solely upon one task (Chang and Hughes, 2012). The business may be driven into a competence pit by a one-sided focus on exploitation practices in which it is unable to respond to changes in the volatile world (Levitt and March, 1988) and give little room for long-term growth (Clarysse et al., 2011). Most analysts thus, believe, from a theoretical point of view, that businesses need to balance their learning by participating in exploratory practices that deliver growth potential and exploitative exercises that create core competencies and, in turn, the capacity for profit potential. At this juncture, spiritual leadership theory is a theory of causal leadership for organizational change from another perspective, intended to establish an internally driven learning enterprise (Fry et al., 2005). The primary goal of this leadership is to build vision and value congruence at the strategic, motivated team and individual levels and eventually to encourage higher levels of internal participation and success to resolve the turbulent scenario (Meng, 2016; Parameshwar, 2005). In particular, theological, ethical and value-based leadership approaches appear to send a loud and simple message that leaders need to recognize their core beliefs and transmit them to followers through vision and personal acts (Blackaby and Blackaby, 2011).

\section{A brief analysis of findings from the interviews}

Six semi-structured interviews have completed in total. Two of the six participants are female decision-makers of SMEs. In addition, four participants are considered as practicing Muslims and two are Non-Muslims (Secular). The Secular segment contains Atheist views and is not connected to any kind of faith-based religious outline. All of the participants hold at least degree certification. The majority of interviewees are between the ages of 35 and 40. 
They all have more than three years of management experience as well. Looking at the results of both the Muslim and Non-Muslim (Secular) categories, a large portion of the interpretation of leadership is identical, but variations can also be found. The results show that the power-influence strategy of Muslim and Non-Muslim managers is essentially the same. In terms of morals, both groups have similar perspectives, but Muslim participants believe their administrative decision-making mechanism is both guardianship and service-oriented.

In reality, the Muslim participants have a proclivity to pursue Allah's gratification in resolving strategic issues of firms about the current severe crisis caused by the COVID-19 pandemic. Non-Muslim decision-makers, on the other hand, attempt to address strategic problems without recourse to Divine contributions. On this note, when an SME's management agrees to reduce pay for any of its workers due to the pandemic situation in Bangladesh, the majority of our practicing Muslim interviewees firmly advocate for some kind of guarantee that the balance will be returned in bonuses if the situation improves. Those two secular interviewees, on the other side, advise firms to manage unjustifiable expenses to remain competitive. At this point, the mirrored Muslim section demonstrates the edge of business empathy, pointing the way toward recognizing not just what a business requires in times of crisis but also what innovative managers must do. The emphatic reinforcement is given to workers focused on Islamic principles aids in the co-development of innovative ideas as the business transitions toward a new standard. Furthermore, the Secular participants sometimes practice Yoga or Meditation for overall well-being. The chosen Muslim participants pray five times a day (Salah), and they believe that mandatory Islamic rituals are very important ingredients for a calm mental state, which adds mindfulness to businesses and unlocks new forms of strategic thought and functioning. It may also help to alleviate managerial stress, fear and insecurity during a crisis. Interestingly, Non-Muslim participants condemn Muslim managers' religiosity in relation to recent terrorist attacks, which could establish a climate of discouragement and skepticism in Bangladesh regarding Islamic leadership configuration (Islam and Abd Wahab, 2021a). Regrettably, we have seen a disparity between the fact presented in Bangladesh's media about Islamic views and the reality itself. Furthermore, the majority of our exploratory results can be attributed to Fry's (2003) research, in which spiritual leadership builds vision and meaning congruence through the firm's strategic configuration to promote higher levels of corporate engagement, adaptability and productivity. However, from an Islamic viewpoint, spiritual leadership in a crisis is not about pressuring others to have or follow the same belief structure, but rather about serving the opportunity to persevere and thereby survive the most stressful of circumstances.

\section{Proposed conceptual framework}

The study considers that spiritual leadership based on the Islamic perspective will affect the success of SMEs in their survival, renewal and growth phases during and after a crisis, as per comprehensive ranges of systematic literature analysis. The presence of strategic innovation practices (exploitation-exploration) also holds the capacity to negotiate the connection between spiritual leadership and the success of SMEs in this context (Figure 2). A connection between the spiritual form of leadership and organizational performance has clearly been identified in the empirical studies of Fry and Matherly (2006), Salehzadeh et al. (2015) and Jeon et al. (2013). Firestone (2020) discusses how religious faith benefits organizations in the sense of a crisis. Some research studies, however, have also provided mixed findings on the relationship between spirituality and success (Javanmard, 2012). However, it is clear that spirituality can strengthen the capacity of an organization to adapt 


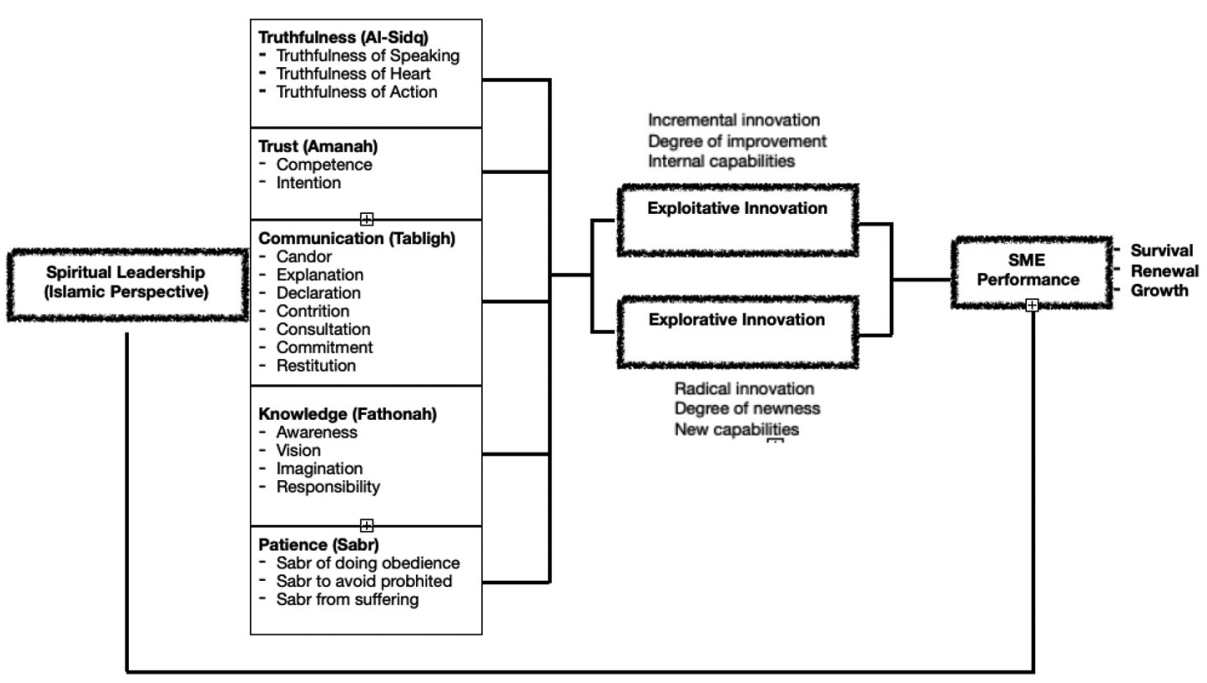

Source: Developed by authors

\section{Role of spiritual leadership in crisis situation}

Figure 2.

SME's holistic crisis handling model

to a crisis in combination with suitable leadership practices. Integrating Islamic ideas and theories will boost the ability of spiritual leadership (Marbun, 2013). Thus, we propose a hypothesis that contends about the holistic link between spiritual leadership and SME performance during and after the COVID-19 crisis.

Innovation as a strategic apparatus, on the other hand, will give SMEs the desired competitive edge to confront amid business uncertainties. Innovation practices are, in effect, necessary for SMEs to produce the desired results to overcome the crisis (Sok et al., 2013). However, a number of studies have shown a strong correlation between SME success based on leadership and innovation (Matzler et al., 2008; Tajasom et al., 2015). A strong relation was formed between a strategic form of leadership and practices of exploitative-explorative innovation initiatives (Jansen et al., 2009). In addition, Hunsaker's (2020) current research explores the connection between the spiritual style of leadership and innovation. The results of Galanou and Farrag (2015) also demonstrate that leadership based on Islamic principles enhances the performance of companies based on innovation. Here, the balance between explorative and exploitative innovation practices can provide policy, transparency and progress that leads to better performance outcomes (Chiu et al., 2011). Therefore, we expect that incorporating spirituality into this configuration will create more holistic productivity for SMEs to solve the current crisis at various levels. At this point, we try to hypothesize that strategic innovation activities (exploitation-exploration) are capable of mediating the relationship between spiritual leadership and SME results, taking into account the whole crisis management scenario (survival, renewal and growth).

\section{Theoretical contributions}

Religion-based spirituality has been largely ignored, if not considered a taboo topic, in strategic paradigms of an organization to handle business uncertainties (Van Buren et al., 2020). The current study indicates that spiritual leadership has the potential to improve the efficiency of SMEs based on strategic innovation through survival, renewal and growth 
phases to cope with crises. In fact, spirituality has exerted an immense power of attraction for researchers, especially because of its novelty in the organizational performance domain (Karakas, 2010). Here, our conceptualization gives researchers a learning opportunity to create a competitive advantage for SMEs focused on holistic outcomes, taking into account the relationship between spiritual leadership and ambidexterity in innovation. In fact, it provides an alternate lens through the proposal of a philosophical paradigm to examine Islamic spirituality-based viewpoints and their related crisis impacts. Furthermore, this view would change orthodox management decision-making doctrines by incorporating the theological component of the Islamic perspective in corporate decision-making processes (Szromek, 2020). In this way, a systemic theoretical model is implemented that reflects on fundamental individual and collective change and is a starting point for future holistic study and refining.

\section{Practical implications}

The path that appears to have a big effect on the capacity of spiritual leadership to allow strategic advancement in the survival, renewal and growth phases of SMEs suggests a higher objective. A higher objective is also a holistic core factor of moral leadership that acts as an overarching framework for crisis management (Coldwell et al., 2012; Fairholm, 1996). This will suggest that leaders and management should look for motivation to solve the condition with greater intent. This is an ideal reaction to the increasing demands for a fresh approach to spiritual leadership in SMEs. Again, the research also has consequences for eliminating ego-based unethical behaviors in everyday leadership practices of organizations by emphasizing the value of paying attention to the pain of others rather than one's own sufferings (Singh, 2019). This kind of empathic leadership thought and activities focused on spiritual value are likely to yield more adaptable solutions that are often associated with a social intent (Vetvik et al., 2018). During uncertainties, it can help to cope with cross-cultural diversity within organizations (Egel and Fry, 2017). Embracing cross-cultural diversity can offer important advantages, such as increased customer support, better decision-making and greater ingenuity and imagination. In addition, these activities are likely to encourage corporate leaders to "walk the talk" over time (after the COVID-19 pandemic) and reclaim lost credibility and confidence with stakeholders.

\section{Final thoughts}

This paper illustrates the holistic view that the spirituality of decision-makers in connection with innovation creates a difference in the capacity of SMEs to succeed and rebound in times of crisis and if so, will and should SMEs aim to foster spirituality based on religion? As a result of this comprehensive investigation, we have developed a configuration that is especially necessary to confront the present crisis because the Muslim or Muslim-majority regions may argue to adjust Western-based leadership structures or the direction of separating faith and function with its increasing percentage (Rostan and Rostan, 2019) of the global working population. In Bangladesh, this scenario can be no different. The pandemic crisis is devastating and long-lasting, but while attempting to do better through tough periods, the way Bangladeshi SME managers or owners respond to this era should be counted, as their interpretation would have a significant effect on any strategic approach that may be applied (Pal et al., 2014). A variety of steps can be taken by Bangladeshi SMEs to strengthen and promote spiritual leadership and spirituality in the workplace to confront the crisis. In SMEs, it is also crucial to build an atmosphere of trust where everybody can collaborate, learn and participate together toward a more holistic and important purpose. The most significant recommendation, perhaps, is the need to promote open communication. 
Here, people should be allowed to talk freely about their religious ideas and how they contribute to the firm performance. It is important to preserve an atmosphere that promotes free speech (Dean and Safranski, 2008). The entire conceptualization requires deep commitment from the Bangladeshi SMEs. The bottom line is that Islamic ideas inside spirituality may help to develop strategic adaptability for SMEs (Burrell, 2021). Ultimately, SMEs can make the entire community a healthier place, more than simply delivering improved business results and efficiency.

The obtained findings indicate that spiritual leadership is based on Islamic perspectives as a systemic non-financial motivational tool that is ideal during and after emergencies in a range of backgrounds, cultures and strategic innovation settings for SMEs. The Islamic method of crisis control for SMEs before and after the COVID-19 pandemic can be derived from the Al Quran and Hadith lessons (Al Eid and Arnout, 2020). At this juncture, spiritual leadership adopting the Islamic viewpoint is an evolutionary and enhanced type of strategic instrument that reflects a high degree of emotional and theological wisdom and sophistication for SMEs across Muslim or Muslim majority countries. It upholds Tawheed (the oneness of Allah) as the source of confidence in leadership with the capacity to confront the current or any crisis. In addition, the research provides some valuable perspectives from the findings gathered, filling a void in the literature of the crisis management overview of the innovation-focused SME through the spiritual leadership process. Nevertheless, as advanced technologies are being exploited at this point to facilitate the response of society to COVID-19 (Islam et al., 2021, 2020; Ting et al., 2020), potential research recommendations also include the call to examine the moderating role of digital technology (Islam and Wahab, 2020) to gain better guidance with regard to the spiritual leadership-oriented crisis management initiatives of Bangladeshi SMEs. There are also several issues relating to spiritual leadership that need to be discussed based on the Islamic context, particularly on the characteristics and behaviors of leaders. Here, because this is a conceptual research paper focused on review study and limited explorative support, no appropriate empirical evidence is collected to generalize to other countries or areas.

\section{References}

Abdelzaher, D., Latheef, Z. and Abdelzaher, A. (2017), "Recovering from conflict and uncertainty post Arab spring”, International Journal of Conflict Management, Vol. 28 No. 2, pp. 222-244.

ACCA (2019), "Combating bribery in the SME sector 2019", ACCA Global, London, available at: www. accaglobal.com/pk/en/professional-insights/global-profession/Combating_bribery_in_the_SME_ sector.html

Adawiyah, W.R. and Pramuka, B.A. (2017), "Scaling the notion of Islamic spirituality in the workplace", Journal of Management Development, Vol. 36 No. 7, pp. 877-898.

ADB (2013), "Finance (small and medium-sized enterprise finance and leasing)", available at: www.adb. $\mathrm{org} / \mathrm{sites} /$ default/files/linked-documents/36200-023-ssa.pdf

Agarwal, R. and Helfat, C.E. (2009), "Strategic renewal of organizations", Organization Science, Vol. 20 No. 2, pp. 281-293.

Akhtar, S., Arshad, M.A., Mahmood, A. and Ahmed, A. (2017), "Spiritual quotient towards organizational sustainability: the Islamic perspective", World Journal of Entrepreneurship, Management and Sustainable Development, Vol. 13 No. 2, pp. 163-170.

Al Eid, N.A. and Arnout, B.A. (2020), "Crisis and disaster management in the light of the Islamic approach: COVID-19 pandemic crisis as a model (a qualitative study using the grounded theory)", Journal of Public Affairs, p. e2217. Role of
spiritual
leadership in
crisis situation 
Ali, M.A. (2016), "Islamic and Western education systems - perceptions of selected educationists in Malaysia”, Journal of Education and Educational Development, Vol. 3 No. 2, pp. 250-276.

Ali, I. and Hatta, Z.A. (2014), "Zakat as a poverty reduction mechanism among the M uslim community: case study of B angladesh, M alaysia, and I ndonesia”, Asian Social Work and Policy Review, Vol. 8 No. 1, pp. 59-70.

Almoharby, D. and Neal, M. (2013), "Clarifying islamic perspectives on leadership", Education, Business and Society: Contemporary Middle Eastern Issues, Vol. 6 Nos 3/4.

Anwar, M.A., Gani, A.M.O. and Rahman, M.S. (2020), "Effects of spiritual intelligence from Islamic perspective on emotional intelligence", Journal of Islamic Accounting and Business Research, Vol. 11 No. 1, pp. 216-232.

Archibugi, D., Filippetti, A. and Frenz, M. (2013), "Economic crisis and innovation: is destruction prevailing over accumulation?”, Research Policy, Vol. 42 No. 2, pp. 303-314.

Auh, S. and Menguc, B. (2005), "Balancing exploration and exploitation: the moderating role of competitive intensity", Journal of Business Research, Vol. 58 No. 12, pp. 1652-1661.

Benefiel, M. and Abbott, M. (2019), Spirituality and Leadership, The Routledge International Handbook of Spirituality in Society and the Professions, pp. 274-279.

Benthall, J. (2016), Islamic Charities and Islamic Humanism in Troubled Times, Manchester University Press.

Beraha, I. and Đuričin, S. (2020), "The impact of COVID-19 crisis on medium-sized enterprises in Serbia”, Economic Analysis, Vol. 53 No. 1, pp. 14-27.

Bieber, R.M. (1988), "Clutch management in a crisis”, Risk Management, Vol. 35 No. 4, p. 72.

bin Khalid, S.H. (2019), "The practices of islamic work ethics and its impact towards the business performance and organizational commitment in small medium enterprises (SME)", Selangor, Doctoral dissertation, Universiti Sains Islam Malaysia.

Blackaby, H.T. and Blackaby, R. (2011), Spiritual Leadership: Moving People on to God's Agenda, B\&H Publishing Group.

Bouckaert, L. and Zsolnai, L. (2011), "Spirituality and business", Handbook of Spirituality and Business, Palgrave Macmillan, London, pp. 3-8.

Bourletidis, K. and Triantafyllopoulos, Y. (2014), "SMEs survival in time of crisis: strategies, tactics and commercial success stories", Procedia - Social and Behavioral Sciences, Vol. 148 No. 1, pp. 639-644.

Bowers, M.R., Hall, J.R. and Srinivasan, M.M. (2017), "Organizational culture and leadership style: the missing combination for selecting the right leader for effective crisis management", Business Horizons, Vol. 60 No. 4, pp. 551-563.

Brammer, S. and Millington, A. (2003), "The effect of stakeholder preferences, organizational structure and industry type on corporate community involvement", Journal of Business Ethics, Vol. 45 No. 3, pp. 213-226.

Brown, M.E. and Mitchell, M.S. (2010), "Ethical and unethical leadership: exploring new avenues for future research", Business Ethics Quarterly, Vol. 20 No. 4, pp. 583-616.

Burrell, D.N. (2021), "Managerial adaptability and business strategic change in age of COVID-19", PSU Research Review.

CFI (2015), "Sharia law", available at: https://corporatefinanceinstitute.com/resources/knowledge/ finance/sharia-law/

Cha, W. and Rew, D. (2018), "CEO characteristics and corporate philanthropy in times of organizational crisis", Journal of General Management, Vol. 44 No. 1, pp. 44-55.

Chang, Y.Y. and Hughes, M. (2012), "Drivers of innovation ambidexterity in small-to medium-sized firms", European Management Journal, Vol. 30 No. 1, pp. 1-17.

Chittithaworn, C., Islam, M.A., Keawchana, T. and Yusuf, D.H.M. (2011), "Factors affecting business success of small and medium enterprises (SMEs) in Thailand", Asian Social Science, Vol. 7 No. 5 , pp. 180-190. 
Chiu, W.H., Chi, H.R., Chang, Y.C. and Chang, H.T. (2011), "Innovation ambidexterity and firm performance: an empirical study of high-tech firms in Taiwan", 2011 International Conference on Information Management, Innovation Management and Industrial Engineering, Vol. 3, IEEE, pp. 475-478.

Clarysse, B., Wright, M. and Van de Velde, E. (2011), "Entrepreneurial origin, technological knowledge, and the growth of spin-off companies", Journal of Management Studies, Vol. 48 No. 6, pp. 14201442.

Coldwell, D.A.L., Joosub, T. and Papageorgiou, E. (2012), "Responsible leadership in organizational crises: an analysis of the effects of public perceptions of selected SA business organizations' reputations", Journal of Business Ethics, Vol. 109 No. 2, pp. 133-144.

Conger, J.A. (1990), “The dark side of leadership”, Organizational Dynamics, Vol. 19 No. 2, pp. 44-55.

CPI (2020), "Corruption perceptions index: research analysis: transparency international", available at: www.transparency.org/en/cpi/2020/index/bgd

Cucculelli, M. and Peruzzi, V. (2020), "Post-crisis firm survival, business model changes, and learning: evidence from the Italian manufacturing industry", Small Business Economics, Vol. 54 No. 2, pp. 459-474.

Daud, W.N.W., Rahim, M.A. and Nasurdin, A.M. (2014), "Quality of Islamic leadership and organizational performance within the takaful industry in Malaysia: a conceptual study", Asian Social Science, Vol. 10 No. 21, p. 135.

De Clercq, D., Haq, I.U., Raja, U., Azeem, M.U. and Mahmud, N. (2018), "When is an Islamic work ethic more likely to spur helping behavior? The roles of despotic leadership and gender", Personnel Review, Vol. 47 No. 3, pp. 630-650.

Dean, K.L. and Safranski, S.R. (2008), "No harm, no foul? Organizational intervention in workplace spirituality", International Journal of Public Administration, Vol. 31 No. 4, pp. 359-371.

Egel, E. and Fry, L.W. (2017), "Spiritual leadership as a model for Islamic leadership”, Public Integrity, Vol. 19 No. 1, pp. 77-95.

Fagerberg, J., Landström, H. and Martin, B.R. (2012), "Exploring the emerging knowledge base of 'the knowledge society", Research Policy, Vol. 41 No. 7, pp. 1121-1131.

Fairholm, G.W. (1996), "Spiritual leadership: fulfilling whole-self needs at work", Leadership and Organization Development Journal, Vol. 17 No. 5, pp. 11-17.

Fernando, M. and Jackson, B. (2006), "The influence of religion-based workplace spirituality on business leaders' decision-making: an inter-faith study", Journal of Management and Organization, Vol. 12 No. 1, pp. 23-39.

Firestone, S. (2020), "Importance of organizational culture to crisis leadership", Biblical Principles of Crisis Leadership, Palgrave Macmillan, Cham, pp. 23-34.

Frisdiantara, C. and Sahertian, P. (2012), "The spiritual leadership dimension in relation to other valuebased leadership in organization", International Journal of Humanities and Social Science, Vol. 2 No. 15, pp. 284-290.

Fry, L.W. (2003), “Toward a theory of spiritual leadership”, The Leadership Quarterly, Vol. 14 No. 6, pp. 693-727.

Fry, L.W. and Matherly, L.L. (2006), "Spiritual leadership and organizational performance: an exploratory study", Annual Meeting of the Academy of Management, (11-16 A ğustos), AtlantaGA, available at: www.tarleton.edu/ fry/sltorgperf.pdf Çağdaş Liderlik Yaklaşımları.

Fry, L.W., Vitucci, S. and Cedillo, M. (2005), "Spiritual leadership and army transformation: theory, measurement, and establishing a baseline", The Leadership Quarterly, Vol. 16 No. 5, pp. 835-862.

Galanou, A. and Farrag, D.A. (2015), "Towards the distinctive Islamic mode of leadership in business", Journal of Management Development, Vol. 34 No. 8, pp. 882-900.

Gazi, M.A.I. (2020), "Islamic perspective of leadership in management; foundation, traits and principles", Int. J. Manag. Account, Vol. 2 No. 1, pp. 1-9. 
Greve, H.R. (2007), "Exploration and exploitation in product innovation", Industrial and Corporate Change, Vol. 16 No. 5, pp. 945-975.

Hart, C. (2001), Doing a Literature Search: A Comprehensive Guide for the Social Sciences, Sage.

Hasan, A. (2003), "An introduction to collective ijtihad (ijtihad jamai): concept and applications", American Journal of Islamic Social Sciences, Vol. 20 No. 2, pp. 26-49.

Haynes, K.T., Hitt, M.A. and Campbell, J.T. (2015), "The dark side of leadership: towards a mid-range theory of hubris and greed in entrepreneurial contexts", Journal of Management Studies, Vol. 52 No. 4, pp. 479-505.

Herbane, B. (2019), "Rethinking organizational resilience and strategic renewal in SMEs", Entrepreneurship and Regional Development, Vol. 31 Nos 5/6, pp. 476-495.

Hong, P., Huang, C. and Li, B. (2012), "Crisis management for SMEs: insights from a multiple-case study", International Journal of Business Excellence, Vol. 5 No. 5, pp. 535-553.

Hoque, N., Khan, M.A. and Mohammad, K.D. (2015), "Poverty alleviation by zakah in a transitional economy: a small business entrepreneurial framework", Journal of Global Entrepreneurship Research, Vol. 5 No. 1, pp. 1-20.

Hossain, M.S. and Yahya, S.B. (2017), "Developing conceptual framework of corporate community development practices of Islamic banks in Bangladesh: an institutional perspective", The Journal of Internet Banking and Commerce, Vol. 22 No. 1, pp. 1-20.

Hughes, M. (2018), "Organisational ambidexterity and firm performance: burning research questions for marketing scholars", Journal of Marketing Management, Vol. 34 Nos 1/2, pp. 178-229.

Hunsaker, W.D. (2020), "Spiritual leadership and employee innovation”, Current Psychology, pp. 1-10. August (2020)

Husti, I. and Mahyarni, M. (2019), "Islamic leadership, innovation, competitive advantages, and performance of SMEs in Indonesia”, East Asia, Vol. 36 No. 4, pp. 369-383.

Illes, K. (2014), Connectedness and Spirituality: A Christian and Hindu Example of Spiritual Based Entrepreneurship, Convergence 2014-Ethical Leadership: The Indian Way.

Islam, A. and Wahab, S. (2020), "Does covid-19 help sustainable business configuration through bigdata analytics (BDA)?", Journal of Arts and Social Sciences, Vol. 4 No. 1, pp. 18-30.

Islam, A. and Abd Wahab, S. (2021a), "The concerns associated with future prospects of the food cart business in Chittagong, Bangladesh: is the concept of halalan tayyiba missing link?", Rajagiri Management Journal, doi: 10.1108/RAMJ-09-2020-0052.

Islam, A. and Abd Wahab, S.A. (2021b), "The intervention of strategic innovation practices in between regulations and sustainable business growth: a holistic perspective for Malaysian SMEs", World Journal of Entrepreneurship, Management and Sustainable Development, doi: 10.1108/WJEMSD04-2020-0035.

Islam, A., Mansoor, A., Rahman, M. and Abd Wahab, S. (2020), "Adjusting a strategic Cash-Flow model for Bangladeshi small and medium enterprises: the art of surviving COVID-19 emergency", Business Excellence and Management, Vol. S.I No. 1, pp. 194-213.

Islam, A., Jerin, I., Hafiz, N., Tali Nimfa, D. and AbdulWahab, S. (2021), "Configuring a blueprint for Malaysian SMEs to survive through the COVID-19 crisis: the reinforcement of quadruple helix innovation model", Journal ofEntrepreneurship, Business and Economics, Vol. 9 No. 1, pp. 32-81.

Jamil, M.Y. (2015), "Islamic perspective of leadership", Journal of Islamic Thought and Civilization (JITC), Vol. 05 No. 02, pp. 24-45.

Jansen, J.J., Vera, D. and Crossan, M. (2009), "Strategic leadership for exploration and exploitation: the moderating role of environmental dynamism", The Leadership Quarterly, Vol. 20 No. 1, pp. 5-18.

Javanmard, H. (2012), "The impact of spirituality on work performance", Indian Journal of Science and Technology, Vol. 5 No. 1, pp. 1961-1966. 
Jeon, K.S., Passmore, D.L., Lee, C. and Hunsaker, W. (2013), "Spiritual leadership: a validation study in a Korean context", Journal of Management, Spirituality and Religion, Vol. 10 No. 4, pp. 342-357.

Juergensen, J., Guimón, J. and Narula, R. (2020), "European SMEs amidst the COVID-19 crisis: assessing impact and policy responses", Journal of Industrial and Business Economics, Vol. 47 No. 3, pp. 499-510.

Karakas, F. (2010), "Spirituality and performance in organizations: a literature review", Journal of Business Ethics, Vol. 94 No. 1, pp. 89-106.

Kaya, A. (2015), "The relationship between spiritual leadership and organizational citizenship behaviors: a research on school principals' behaviors", Educational Sciences: Theory and Practice, Vol. 15 No. 3, pp. 597-606.

Khurshid, M.A., Al-Aali, A., Soliman, A.A. and Amin, S.M. (2014), "Developing an Islamic corporate social responsibility model (ICSR)”, Competitiveness Review, Vol. 24 No. 4, pp. 258-274.

Kovács, G. (2020), "Business spirituality", The Value Orientations of Buddhist and Christian Entrepreneurs, Palgrave Macmillan, Cham, pp. 61-93.

Levitt, B. and March, J.G. (1988), “Organizational learning”, Annual Review of Sociology, Vol. 14 No. 1, p. 319340.

LightCastle (2020), COVID-19 Impact on the SME Sector of Bangladesh, Dhaka.

Looser, S. (2020), "Strategies, growth and innovation: are there any interlinked management configurations?", Intrinsic CSR and Competition, Palgrave Macmillan, Cham, pp. 233-239.

Mabey, C., Conroy, M., Blakeley, K. and de Marco, S. (2017), "Having burned the straw man of Christian spiritual leadership, what can we learn from jesus about leading ethically?", Journal of Business Ethics, Vol. 145 No. 4, pp. 757-769.

Machmud, A. and Hidayat, Y.M. (2020), "Characteristics of islamic entrepreneurship and the business success of SMEs in Indonesia”, Journal of Entrepreneurship Education, Vol. 23 No. 2, pp. 1-16.

Maldonado-Erazo, C.P., Álvarez-García, J., del Río-Rama, M.D.L.C. and Correa-Quezada, R. (2020), "Corporate social responsibility and performance in SMEs: scientific coverage", Sustainability, Vol. 12 No. 6, p. 2332.

Marbun, D.S. (2013), "Attributions and requirements of Islamic leadership", Management Research Review, Vol. 36 No. 4, pp. 379-387.

March, J.G. (1991), "Exploration and exploitation in organizational learning", Organization Science, Vol. 2 No. 1, pp. 71-87.

Matzler, K., Schwarz, E., Deutinger, N. and Harms, R. (2008), "The relationship between transformational leadership, product innovation and performancein SMEs", Journal of Small Business and Entrepreneurship, Vol. 21 No. 2, pp. 139-151.

Mebroui, T. and Mosbah, A. (2020), "Islamic entrepreneurship: issues and debates", International Journal of Management and Commerce Innovations, Vol. 7 No. 2, pp. 461-468.

Meng, Y. (2016), "Spiritual leadership at the workplace: perspectives and theories", Biomedical Reports, Vol. 5 No. 4, pp. 408-412.

Mir, A.M. (2010), “Leadership in Islam”, Journal of Leadership Studies, Vol. 4 No. 3, pp. $69-72$.

Miroshnychenko, I., De Massis, A., Miller, D. and Barontini, R. (2020), "Family business growth around the world", Entrepreneurship Theory and Practice, p. 1042258720913028.

Mohiuddin, M.F. (2017), "Islamic social enterprises in Bangladesh: conceptual and institutional challenges", Cogent Business and Management, Vol. 4 No. 1, p. 1305674.

Moretti, D.M., Alves, F.C. and Bomtempo, J.V. (2020), "Entrepreneurial-oriented strategic renewal in a Brazilian SME: a case study", Journal of Small Business and Enterprise Development, Vol. 27 No. 2, pp. 219-236. 
Naidoo, V. (2010), "Firm survival through a crisis: the influence of market orientation, marketing innovation and business strategy", Industrial Marketing Management, Vol. 39 No. 8, pp. 1311-1320.

Nelson, M.J. (2008), "Religious education in non-religious schools: a comparative study of Pakistan and Bangladesh", Commonwealth and Comparative Politics, Vol. 46 No. 3, pp. 271-295.

Nisha, N. and Iqbal, M. (2017), "Halal ecosystem: prospect for growth in Bangladesh", International Journal of Business and Society, Vol. 18 No. S1, pp. 205-222.

Pal, R., Torstensson, H. and Mattila, H. (2014), "Antecedents of organizational resilience in economic crises - an empirical study of Swedish textile and clothing SMEs", International Journal of Production Economics, Vol. 147 No. 1, pp. 410-428.

Parameshwar, S. (2005), "Spiritual leadership through ego-transcendence: exceptional responses to challenging circumstances", The Leadership Quarterly, Vol. 16 No. 5, pp. 689-722.

Park, S., Lee, I.H. and Kim, J.E. (2019), “Government support and small-and medium-sized enterprise (SME) performance: the moderating effects of diagnostic and support services", Asian Business and Management, Vol. 19 No. 2, pp. 213-238.

Paunov, C. (2012), "The global crisis and firms' investments in innovation”, Research Policy, Vol. 41 No. 1, pp. 24-35.

Porter, M. and Kramer, M. (2002), "The competitive advantage of corporate philanthropy", Harvard Business Review, Retrieved 20 April 2021, available at: https://hbr.org/2002/12/the-competitiveadvantage-of-corporate-philanthropy

Rafiki, A. (2020), "Islamic leadership: comparisons and qualities", Digital Leadership-A New Leadership Style for the 21st Century, IntechOpen.

Rahman, M.M. (2020), "Re-Examining the nexus between madrasa education and politics in Bangladesh", South Asia: Journal of South Asian Studies, Vol. 43 No. 4, pp. 613-631.

Rainey, D.L. (2010), Sustainable Business Development: inventing the Future through Strategy, Innovation, and Leadership, Cambridge university press.

Ramadani, V., Dana, L.P., Ratten, V. and Tahiri, S. (2015), "The context of Islamic entrepreneurship and business: concept, principles and perspectives", International Journal of Business and Globalisation, Vol. 15 No. 3, pp. 244-261.

Ramli, A., Mokhtar, M. and Aziz, B.A. (2014), "Revisiting the concept of development, disaster and safety management: the quranic perspective", International Journal of Disaster Risk Reduction, Vol. 9 No. 1, pp. 26-37.

Reave, L. (2005), "Spiritual values and practices related to leadership effectiveness", The Leadership Quarterly, Vol. 16 No. 5, pp. 655-687.

Reymen, I.M., Andries, P., Berends, H., Mauer, R., Stephan, U. and Van Burg, E. (2015), “Understanding dynamics of strategic decision making in venture creation: a process study of effectuation and causation", Strategic Entrepreneurship Journal, Vol. 9 No. 4, pp. 351-379.

Richard, P.J., Devinney, T.M., Yip, G.S. and Johnson, G. (2009), "Measuring organizational performance: towards methodological best practice", Journal of Management, Vol. 35 No. 3, pp. 718-804.

Rostan, P. and Rostan, A. (2019), "When will European Muslim population be majority and in which country?”, PSU Research Review, Vol. 3 No. 2, pp. 123-144.

Roy, S., Huq, S. and Rob, A.B.A. (2020), "Faith and education in Bangladesh: a review of the contemporary landscape and challenges", International Journal of Educational Development, Vol. 79 No. 1, p. 102290.

Safi, L. (1995), "Leadership and subordination: an Islamic perspective", American Journal of Islam and Society, Vol. 12 No. 2, pp. 204-223.

Salehzadeh, R., Pool, J.K., Lashaki, J.K., Dolati, H. and Jamkhaneh, H.B. (2015), "Studying the effect of spiritual leadership on organizational performance: an empirical study in hotel industry", International Journal of Culture, Tourism and Hospitality Research, Vol. 9 No. 3, pp. 346-359. 
Satar, D. (2019), "Corruption a big issue in muslim-majority nations", New Straits Times. Retrieved 17 April 2021, available at: www.nst.com.my/opinion/columnists/2019/04/480813/corruption-bigissue-muslim-majority-nations

Saunders, M.N., Gray, D.E. and Goregaokar, H. (2014), "SME innovation and learning: the role of networks and crisis events", European Journal of Training and Development, Vol. 38 Nos 1/2, pp. 136-149.

Seuring, S. and Müller, M. (2008), "From a literature review to a conceptual framework for sustainable supply chain management", Journal of Cleaner Production, Vol. 16 No. 15, pp. 1699-1710.

Shirokova, G., Osiyevskyy, O., Laskovaia, A. and MahdaviMazdeh, H. (2020), "Navigating the emerging market context: performance implications of effectuation and causation for small and medium enterprises during adverse economic conditions in Russia”, Strategic Entrepreneurship Journal, Vol. 14 No. 3, pp. 470-500.

Sholikhah, Z., Wang, X. and Li, W. (2019), "The role of spiritual leadership in fostering discretionary behaviors", International Journal of Law and Management, Vol. 61 No. 1, pp. 232-249.

Singh, S. (2019), "The Impact of workplace spirituality on employees' productivity and their wellbeing", Global Journal of Enterprise Information System, Vol. 11 No. 1, pp. 54-63.

Sok, P., O'Cass, A. and Sok, K.M. (2013), “Achieving superior SME performance: Overarching role of marketing, innovation, and learning capabilities”, Australasian Marketing Journal (AMJ), Vol. 21 No. 3, pp. 161-167.

Stern, E.K. (2017), "Crisis, leadership, and extreme contexts", Leadership in Extreme Situations, Springer, Cham, pp. 41-59.

Sui, S. and Baum, M. (2014), "Internationalization strategy, firm resources and the survival of SMEs in the export market”, Journal of International Business Studies, Vol. 45 No. 7, pp. 821-841.

Sultana, A. and Kabir, S.M. (2018), "Inferiority complex and self-esteem among madrasa students in Bangladesh: a real crisis", Illness, Crisis and Loss, p. 1054137318813059.

Szromek, A.R. (2020), "The importance of spiritual values in the process of managerial decision-making in the enterprise", Sustainability, Vol. 12 No. 13, p. 5423.

Tajasom, A., Hung, D.K.M., Nikbin, D. and Hyun, S.S. (2015), "The role of transformational leadership in innovation performance of Malaysian SMEs", Asian Journal of Technology Innovation, Vol. 23 No. 2, pp. 172-188.

The Daily Star (2018), "Master's status for top qawmi degree: towards legal recognition”, Retrieved 18 April 2021, available at: www.thedailystar.net/news/country/bangladesh-cabinet-approves-billrecognising-qawmi-madrasahs-dawrae-hadith-1620178

Ting, D.S.W., Carin, L., Dzau, V. and Wong, T.Y. (2020), "Digital technology and COVID-19", Nature Medicine, Vol. 26 No. 4, pp. 459-461.

Tobroni, T. (2015), "Spiritual leadership: a solution of the leadership crisis in Islamic education in Indonesia”, British Journal of Education, Vol. 3 No. 11, pp. 40-53.

Van Buren, H.J., III, Syed, J. and Mir, R. (2020), "Religion as a macro social force affecting business: concepts, questions, and future research", Business and Society, Vol. 59 No. 5, pp. 799-822.

Vetvik, E., Danbolt, T., Furman, L.D., Benson, P.W. and Canda, E.R. (2018), "A comparative analysis of Norwegian and American social workers' views about inclusion of religion and spirituality in social work", Journal of Religion and Spirituality in Social Work: Social Thought, Vol. 37 No. 2, pp. $105-127$.

Warf, B. (2017), “Geographies of African corruption”, PSU Research Review, Vol. 1 No. 1, pp. 20-38.

White, E. (1986), "The crisis in Christian leadership”, Review and Expositor, Vol. 83 No. 4, pp. 545-557.

Wilson, R. (2006), "Islam and business", Thunderbird International Business Review, Vol. 48 No. 1, pp. 109-123. 
World Bank (2020), "SMALL aND MEDIUM ENTERPRISES (SMES) FINANCE. Washington DC: WB", available at: www.worldbank.org/en/topic/smefinance

Zhang, Y. and Yang, F. (2020), "How and when spiritual leadership enhances employee innovative behavior", Personnel Review, Vol. 50 No. 2.

Zuraik, A. and Kelly, L. (2019), "The role of CEO transformational leadership and innovation climate in exploration and exploitation", European Journal of Innovation Management, Vol. 22 No. 1, pp. 84-104.

\section{Further reading}

Headd, B. (2003), "Redefining business success: distinguishing between closure and failure", Small Business Economics, Vol. 21 No. 1, pp. 51-61.

\section{Corresponding author}

Ariful Islam can be contacted at: farhan_ctg2012@yahoo.com

For instructions on how to order reprints of this article, please visit our website: www.emeraldgrouppublishing.com/licensing/reprints.htm

Or contact us for further details: permissions@emeraldinsight.com 